\title{
Synthesis and circularly polarized luminescence properties of BINOL-derived bisbenzofuro[2,3-b:3',2'-e]pyridines (BBZFPys)
}

\author{
Ryo Takishima ${ }^{1}$, Yuji Nishii ${ }^{*}$, Tomoaki Hinoue ${ }^{1}$, Yoshitane Imai ${ }^{3}$ and Masahiro Miura ${ }^{* 1}$
}

\section{Full Research Paper}

Address:

${ }^{1}$ Department of Applied Chemistry, Graduate School of Engineering, Osaka University, Suita, Osaka 565-0871, Japan, ${ }^{2}$ Frontier Research Base for Global Young Researchers, Graduate School of Engineering, Osaka University, Suita, Osaka 565-0871, Japan and ${ }^{3}$ Department of Applied Chemistry, Faculty of Science and Engineering, Kindai University, Higashi-Osaka, Osaka 577-8502, Japan

\section{Email:}

Yuji Nishii $^{*}$ - y_nishii@chem.eng.osaka-u.ac.jp; Masahiro Miura* miura@chem.eng.osaka-u.ac.jp

* Corresponding author

Keywords:

BINOL; C-H activation; circularly polarized luminescence; palladium
Beilstein J. Org. Chem. 2020, 16, 325-336.

doi:10.3762/bjoc. 16.32

Received: 07 January 2020

Accepted: 21 February 2020

Published: 06 March 2020

This article is part of the thematic issue "C-H functionalization for materials science".

Guest Editor: K. Itami

(C) 2020 Takishima et al.; licensee Beilstein-Institut.

License and terms: see end of document.

\begin{abstract}
A series of optically active bisbenzofuro[2,3-b:3',2'-e]pyridine (BBZFPy) derivatives was synthesized starting with the readily available $(S)$ - and $(R)$-1,1'-bi-2-naphthols through a palladium-catalyzed multiple intramolecular $\mathrm{C}-\mathrm{H} / \mathrm{C}-\mathrm{H}$ coupling as the key ring-closure step. The effect of terminal tert-butyl substituents on the BBZFPy skeleton was systematically investigated to uncover a unique aggregation-induced enhancement of CPL characteristics in the solid state. The crystal structures of the coupling products were also evaluated by single crystal X-ray analysis and the well-ordered intermolecular stacking arrangements appeared to be responsible for the enhanced CPL.
\end{abstract}

\section{Introduction}

Densely-fused (hetero)aromatic compounds have been a key motif in a wide range of manufactured functional molecules, as they exhibit fundamentally useful electrochemical and photophysical properties. Considerable effort has therefore taken into the development of efficient methods for the construction of such polycyclic scaffolds, and the last decade has witnessed a remarkable improvement in the palladium-catalyzed $\mathrm{C}-\mathrm{H} / \mathrm{C}-\mathrm{H}$ oxidative coupling as one of the potential synthetic strategies
[1]. This method is straightforward and highly step-economical, enabling us to produce condensed (hetero)acenes from rather simple polyarenes, in which several aromatic units are connected with each other through appropriate linker units [2-11]. Recently, we reported the synthesis and optical properties of a series of furan-fused aromatics via the formal dehydrogenative coupling adopting oxygen atom as the linker [12-17]. In particular, bisbenzofuro[2,3-b:3',2'-e]pyridines (BBZFPys) 
were found to exhibit intense photoluminescence with relatively high quantum efficiency ( $\Phi_{\text {flu }}$ up to 0.70 ), indicating that the BBFZPy scaffold may serve as a key fluorophore unit in certain light-emitting functional materials (Scheme 1) [14].

Meanwhile, organic optoelectronic materials with circularly polarized luminescence (CPL) characteristics have attracted significant research interests in recent years [18-21] for their potential applications in three-dimensional displays [22], information storage systems [23], molecular photoswitches [24], etc. Among a series of chiral scaffolds for CPL emitting molecules, axially chiral 1,1'-bi-2-naphthol (BINOL) has been frequently adopted for the core structure owing to the availability of both enantiomers as well as the ease of site-selective functionalization. Up to date, many BINOL-based CPL active compounds have been established by installing aromatic subunits on the periphery of the binaphthyl skeleton or on the hydroxy groups [25-32], extending the $\pi$-system [33], and linearly connecting the naphthyl rings [34-36]. In these compounds, the hydroxy groups are remained untouched or protected as the corresponding ethers or esters. We envisioned that the assembly of the binaphthyl-fused furan motif embedding the BINOL hydroxy groups into the polyaromatic scaffolds would lead to the development of new chiroptical materials. Such molecules, however, have hardly been investigated to date probably because of the synthetic difficulty to obtain them as pure enantiomers. There have been only a few reports for the binaphthyl-fused furan-ring construction from the C3-alkynylated BINOL derivatives [3739]. In this context, we herein describe the synthesis of axially chiral BINOL-derived BBZFPys through the palladium-catalyzed oxidative coupling reaction. The optical properties of the synthesized polyaromatic compounds were systematically studied, and some of them displayed an interesting aggregationinduced enhancement of CPL in the solid state with considerably higher dissymmetry factors compared to those in solution.

\section{Results and Discussion \\ Synthesis of BINOL-derived BBFPys}

The study was initiated with the synthesis of 2,6-diaryloxypyridines 3 bearing a 1,1'-binaphthyl backbone as precursors for the dehydrogenative coupling reaction (Scheme 2). In general, functionalization of the BINOL hydroxy groups should be performed at temperatures below $80^{\circ} \mathrm{C}$ to prevent racemization [40,41]. 6,6'-Di-tert-butyl-1,1'-bi-2-naphthol (1) was treated with 2,6-difluoropyridine using cesium carbonate as base in DMF at $40{ }^{\circ} \mathrm{C}$ [42], giving both the enantiomers of 2 in optically pure forms. The remaining fluorine substituents were subsequently replaced by a series of phenols including unsubstituted phenol, $p$-tert-butylphenol, and $m$-tert-butylphenol to produce the corresponding unsymmetrically substituted pyridines 3a-c in high yields. We then examined the oxidative cyclization of these compounds under the standard conditions

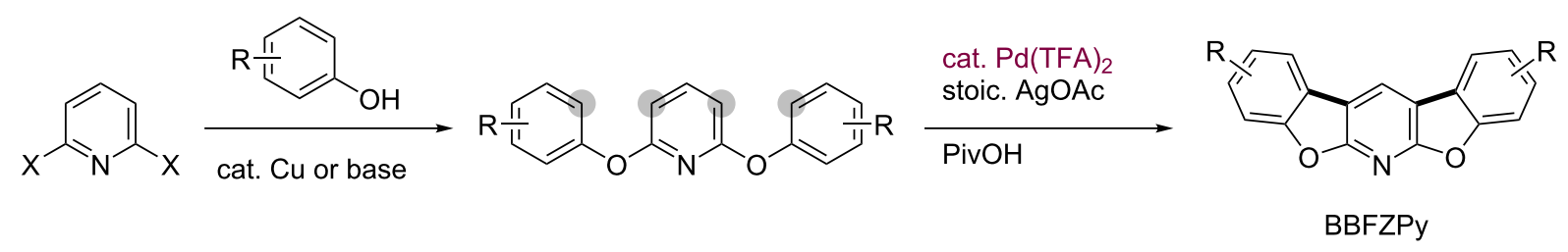

Scheme 1: Synthesis of BBFZPys through the Pd-catalyzed C-H/C-H coupling.

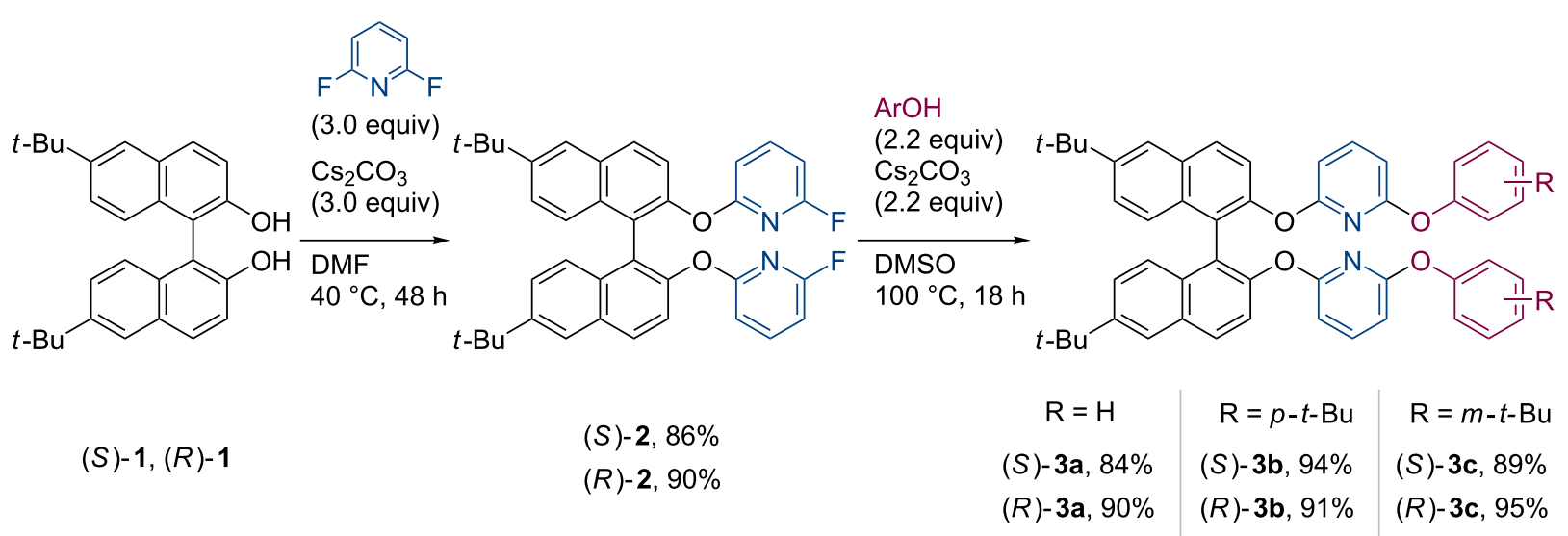


adopting $\mathrm{Pd}(\mathrm{TFA})_{2}(30 \mathrm{~mol} \%$, TFA $=$ trifluoroacetate $)$ and $\mathrm{AgOAc}$ (3.0 equiv) as catalyst and oxidant, respectively, in pivalic acid as solvent (Scheme 3). Since the desired four-fold coupling products 4 were obtained only in small quantities after the reactions, the crude mixtures containing incompletely cyclized compounds were again subjected to the same catalytic conditions. To our delight, all the target molecules $4 \mathbf{a}-\mathbf{c}$ were successfully isolated as pure enantiomers in $10-36 \%$ yields. The higher yield of $\mathbf{4} \mathbf{c}$ was probably due to its better solubility.

In order to systematically evaluate the optical properties of these coupling products, a simple benzofuran-fused 1,1'-binaphthyl 6 was also synthesized as a benchmark (Scheme 4). The parent ether $\mathbf{5}$ was obtained through the arylation of $\mathbf{1}$ utilizing $\mathrm{Ph}_{2}$ IOTf as arylating reagent $[43,44]$. Some coppermediated arylation protocols using bromobenzene or iodobenzene $[45,46]$ were also applicable to the preparation of $\mathbf{5}$, but significant loss of optical purity was inevitable. After the Pd-catalyzed cyclization under the standard conditions, the desired compounds $(S)$ - and $(R)-6$ were obtained as pure enantiomers in $18 \%$ yield.

\section{Optical properties}

We next investigated the optical properties of the coupling products (Figure 1 and Table 1). The parent compounds 3a-c emitted fluorescence at around $360 \mathrm{~nm}$ both in sufficiently diluted $\mathrm{CHCl}_{3}$ solutions $\left(1.0 \times 10^{-5} \mathrm{M}\right)$ and in the solid states. The quantum yields of these molecules were around 0.15 in solution, which is typical for binaphthyl compounds [47]. In contrast, 4a-c as well as $\mathbf{6}$ exhibited fluorescence at around $390 \mathrm{~nm}$ in solution, with relatively higher quantum yields of 0.37-0.40. The emission bands of $\mathbf{4 a - c}$ in their solid state were considerably red-shifted as compared to that of $\mathbf{6}$, suggesting that these compounds displayed the appreciable effect of molecular aggregation. Interestingly, $\mathbf{4 b}$ and $\mathbf{4 c}$, bearing the additional terminal tert-butyl substituents, were more red-shifted than 4a despite such a sterically demanding group usually disturbs intermolecular stacking interactions.

Subsequently, the chiroptical properties of the synthesized compounds were evaluated (Figure 2 and Figure 3, Table 2). The circular dichroism (CD) spectra in $\mathrm{CHCl}_{3}$ solutions showed apparent Cotton signals characteristic to axially chiral mole-

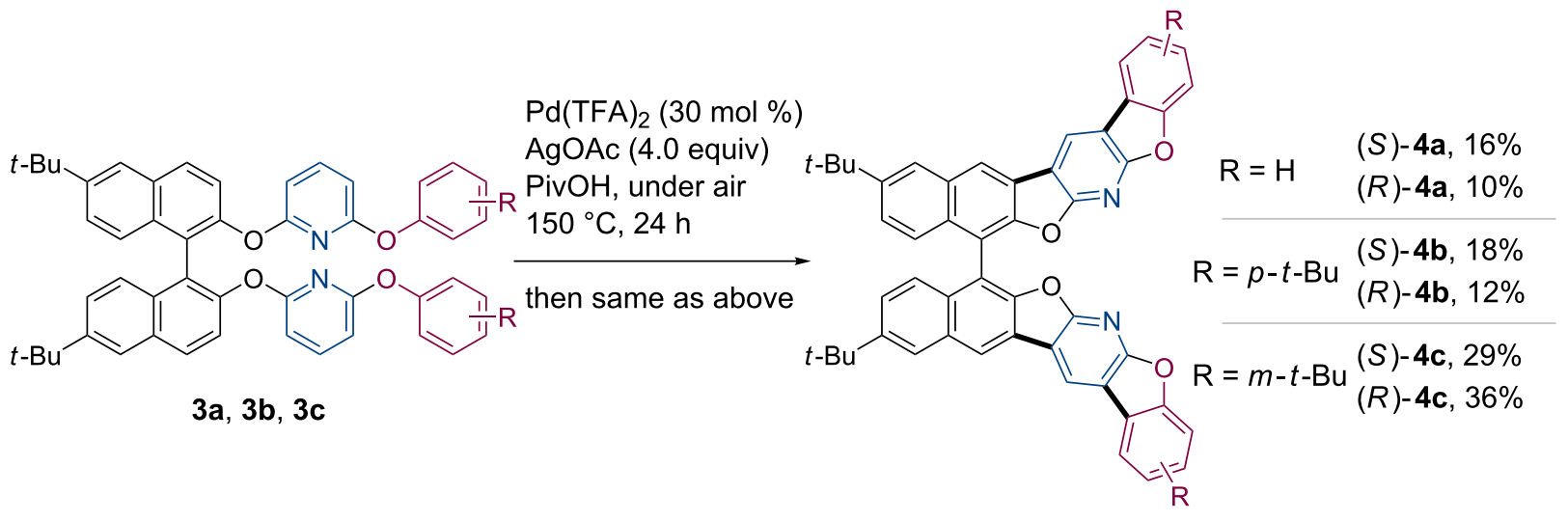

Scheme 3: Synthesis of $4 a-c$ through oxidative coupling reaction.

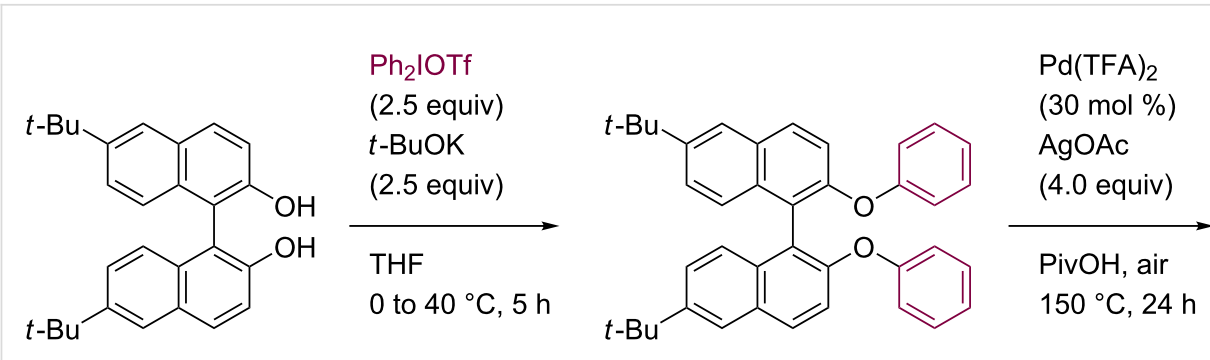

$(S)-1,(R)-1$
(S)-5, 58\%

(R)-5, 62\%<smiles>CC(C)(C)c1ccc2c(-c3c4ccc(C(C)(C)C)cc4cc4c3oc3ccccc34)c3oc4ccccc4c3cc2c1</smiles>

(S)-6, $18 \%$

(R)-6, $18 \%$ 

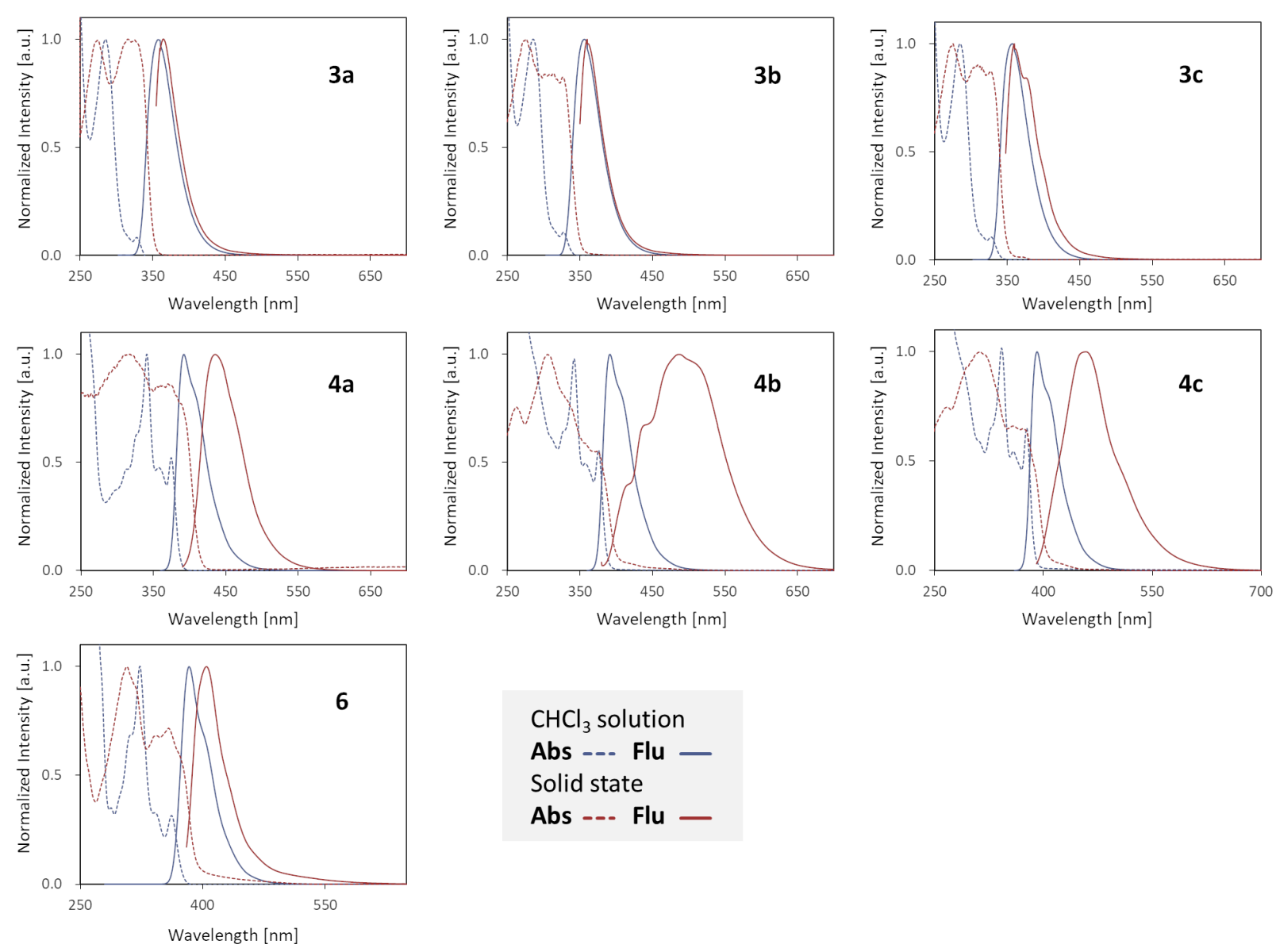

$$
\begin{aligned}
& \mathrm{CHCl}_{3} \text { solution } \\
& \text { Abs --- Flu - } \\
& \text { Solid state } \\
& \text { Abs --- Flu - }
\end{aligned}
$$

\begin{tabular}{|c|c|c|c|c|}
\hline Compd. & solution $\lambda_{\max }\left(\lambda_{\mathrm{ex}}\right)$ & solid $\lambda_{\max }\left(\lambda_{\mathrm{ex}}\right)$ & $\Phi$ (solution) & $\Phi$ (solid) \\
\hline $3 a$ & 358 nm (282 nm) & 360 nm (341 nm) & 0.13 & 0.30 \\
\hline $3 b$ & 357 nm (283 nm) & 360 nm (338 nm) & 0.14 & 0.21 \\
\hline $3 c$ & 357 nm (283 nm) & 360 nm (338 nm) & 0.16 & 0.19 \\
\hline $4 a$ & 392 nm (341 nm) & $436 \mathrm{~nm}(369 \mathrm{~nm})$ & 0.39 & 0.17 \\
\hline $4 b$ & 391 nm (342 nm) & 488 nm (369 nm) & 0.38 & 0.08 \\
\hline $4 c$ & 391 nm (342 nm) & 457 nm (370 nm) & 0.40 & 0.07 \\
\hline 6 & $384 \mathrm{~nm}(263 \mathrm{~nm})$ & $405 \mathrm{~nm}(380 \mathrm{~nm})$ & 0.37 & 0.13 \\
\hline
\end{tabular}

Figure 1: Absorption (dotted line) and fluorescence (solid line) spectra of $\mathbf{3}, \mathbf{4}$, and $\mathbf{6}$ measured as $\mathrm{CHCl}_{3}$ solutions $\left(1.0 \times 10^{-5} \mathrm{M}\right)$ and in solid states.

a Measured at room temperature as solution in $\mathrm{CHCl}_{3}\left(1.0 \times 10^{-5} \mathrm{M}\right)$ and in the solid states.

cules. In all cases, the $(S)$ - and $(R)$-enantiomers were evidently mirror images of each other while the anisotropy factors $g_{\text {abs }}$ are relatively small and in the range of $10^{-4}$ to $10^{-7}$. The spec- tral shapes of $\mathbf{3 a}-\mathbf{c}$ and $\mathbf{4 a}-\mathbf{c}$ were respectively comparable, indicating that the posted positions of the terminal tert-butyl groups exerted minimal influence on the Cotton effect in the 


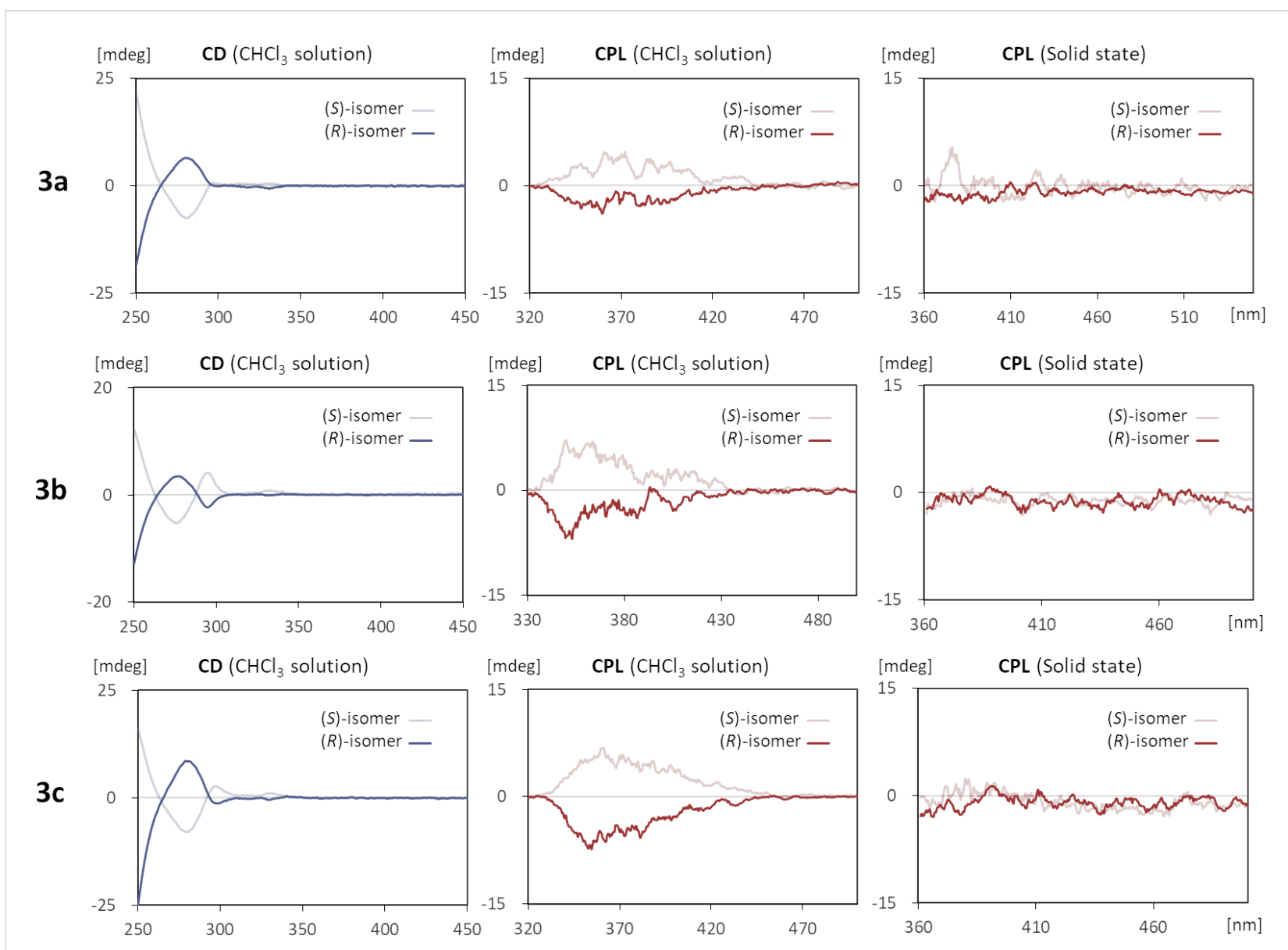

Figure 2: $\mathrm{CD}$ and $\mathrm{CPL}$ spectra of 3 measured as $\mathrm{CHCl}_{3}$ solutions $\left(1.0 \times 10^{-5} \mathrm{M}\right)$ and in the solid states (dispersed in Fomblin ${ }^{\circledR}$ ).

\begin{tabular}{|c|c|c|c|}
\hline Compd. & $g_{\text {abs }}($ solution) & $g_{\text {lum }}$ (solution) & $g_{\text {lum }}($ solid $)$ \\
\hline $3 a$ & $8.72 \times 10^{-7}(285 \mathrm{~nm})$ & $4.37 \times 10^{-4}(358 \mathrm{~nm})$ & n.d. ${ }^{b}$ \\
\hline $3 b$ & $3.18 \times 10^{-7}(285 \mathrm{~nm})$ & $6.72 \times 10^{-4}(357 \mathrm{~nm})$ & n.d. ${ }^{b}$ \\
\hline $3 c$ & $1.06 \times 10^{-6}(285 \mathrm{~nm})$ & $6.90 \times 10^{-4}(357 \mathrm{~nm})$ & n.d. ${ }^{b}$ \\
\hline $4 a$ & $5.60 \times 10^{-6}(341 \mathrm{~nm})$ & $5.57 \times 10^{-4}(392 \mathrm{~nm})$ & $5.40 \times 10^{-4}(436 \mathrm{~nm})$ \\
\hline $4 b$ & $9.96 \times 10^{-5}(342 \mathrm{~nm})$ & $4.60 \times 10^{-4}(391 \mathrm{~nm})$ & $6.68 \times 10^{-3}(488 \mathrm{~nm})$ \\
\hline $4 c$ & $8.72 \times 10^{-5}(342 \mathrm{~nm})$ & $6.40 \times 10^{-4}(391 \mathrm{~nm})$ & $6.06 \times 10^{-3}(457 \mathrm{~nm})$ \\
\hline 6 & $1.00 \times 10^{-4}(256 \mathrm{~nm})$ & $3.80 \times 10^{-4}(384 \mathrm{~nm})$ & $1.40 \times 10^{-4}(405 \mathrm{~nm})$ \\
\hline
\end{tabular}

aMeasured at room temperature as solution in $\mathrm{CHCl}_{3}\left(1.0 \times 10^{-5} \mathrm{M}\right)$ and in solid states (dispersed in Fomblin $\left.{ }^{\circledR}\right)$. ${ }^{\mathrm{b}} \mathrm{Not}$ determined.

solution state. A similar trend was observed for the CPL spectra. The $(S)$-isomers displayed left-handed CPL characteristics throughout the wavelengths of their corresponding fluorescence emission bands, whereas the $(R)$-isomers emitted right- handed CPL to produce the mirror images. The calculated luminescence dissymmetry factors [48] $g_{\text {lum }}$ for the solutions were all within the range of $3.80 \times 10^{-4}$ to $6.90 \times 10^{-4}$. On the other hand, in the dispersed solid state in Fomblin ${ }^{\circledR}$ PFPE (perfluo- 


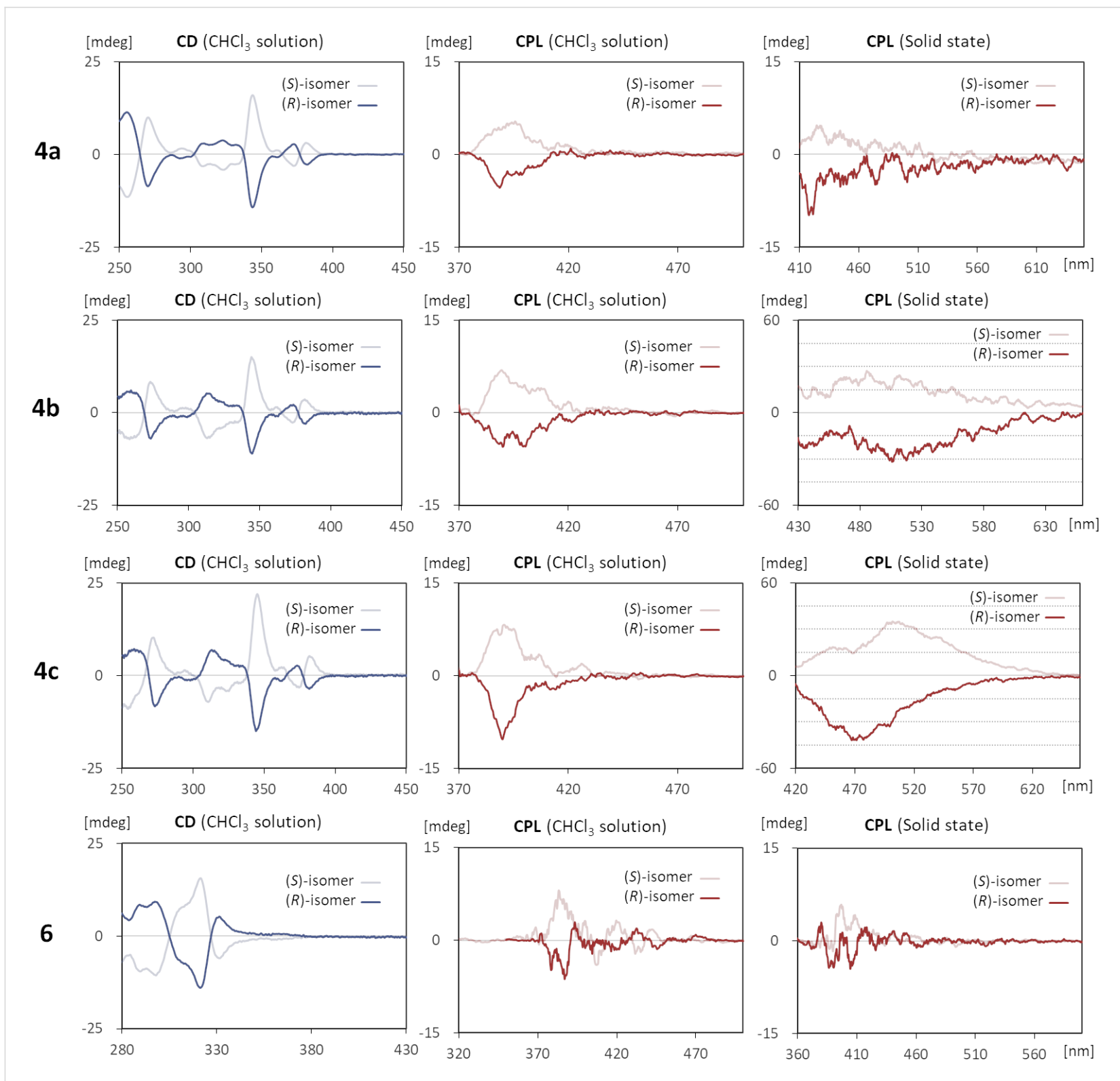

Figure 3: $\mathrm{CD}$ and $\mathrm{CPL}$ spectra of $\mathbf{4}$ and $\mathbf{6}$ measured as $\mathrm{CHCl}_{3}$ solutions $\left(1.0 \times 10^{-5} \mathrm{M}\right)$ and in solid states (dispersed in Fomblin ${ }^{\circledR}$ ).

ropolyether) fluid (each sample was not soluble in the fluid and gave the expected solid-state luminescence), the signal intensity drastically changed depending on the molecular structures. In particular, $\mathbf{4 b}$ and $\mathbf{4 c}$ exhibited enhanced CPL characteristics with considerably high $g_{\text {lum }}$ values of $6.68 \times 10^{-3}$ and $6.06 \times 10^{-3}$, respectively, which were approximately ten times larger than those of the $\mathrm{CHCl}_{3}$ solutions [49]. The parent compounds 3a-c, however, did not give clear mirror images in the CPL measurements. Since such a phenomenon was not observed for $\mathbf{4 a}$ and $\mathbf{6}$, the terminal tert-butyl substituents in $\mathbf{4 b}$ and $\mathbf{4 c}$ were likely to assist the formation of well-ordered aggregates, being consistent with the observation of the red-shifted luminescence discussed above.

\section{Crystal structures of $\mathbf{4 b}$ and $\mathbf{4 c}$}

The molecular structures of $\mathbf{4 b}$ and $\mathbf{4 c}$ were unambiguously determined by single crystal $\mathrm{X}$-ray diffraction analysis. The crystal of $\mathbf{4 b}$ is classified into a space group $P 4_{3} 22$ (tetragonal) with a biaryl torsion angle of $74.4^{\circ}$ (Figure 4 b). A considerable intermolecular $\pi-\pi$ stacking interaction was observed in between its polyaromatic fragments whose distance is approximately $3.44 \AA$. The polycyclic subunits overlap each other, being line-symmetrically aligned (Figure 5a). Meanwhile, the isomer $\mathbf{4 c}$ has two independent molecules in the unit cell, and the torsion angles are $67.1^{\circ}$ and $106.8^{\circ}$, respectively (Figure $4 \mathrm{~d}$ and $4 \mathrm{f}$ ). As displayed in Figure $4 \mathrm{~b}$, the aromatic fragments are point-symmetrically overlapped with the $\pi-\pi$ stacking distance 
(a) side view of $(R)-4 \mathbf{b}$

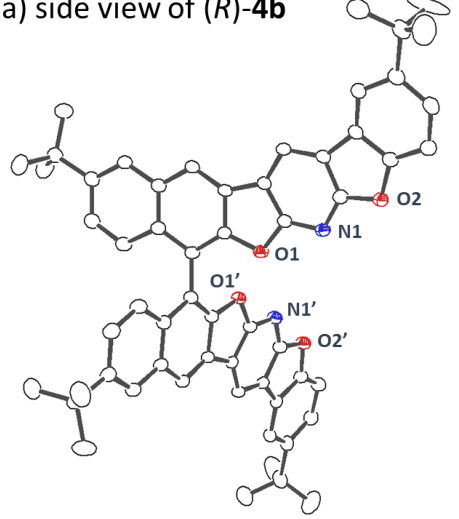

(b) top view of $(R)-\mathbf{4 b}$

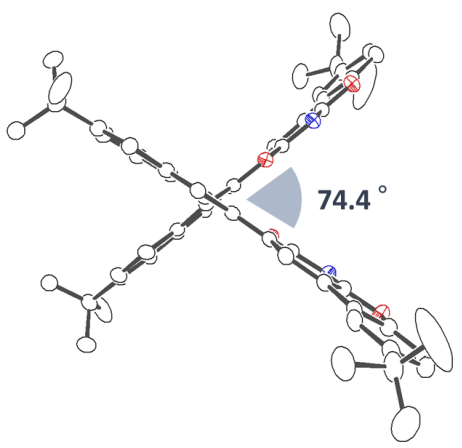

(c) side view of $(R)-4 \mathrm{c}-1$

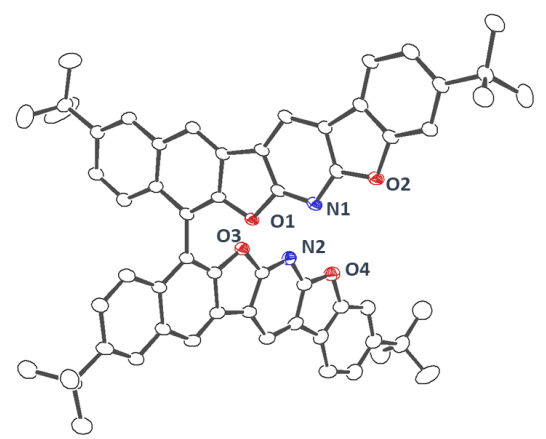

(d) top view of $(R)-4 \mathrm{c}-1$

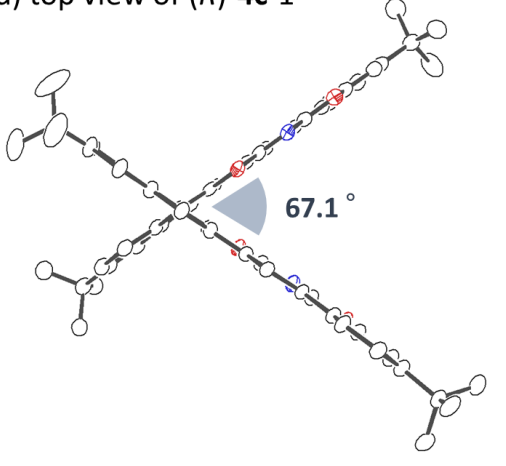

(e) side view of $(R)-4 c-2$

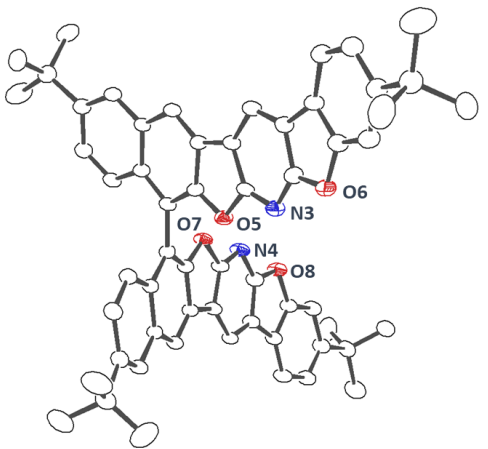

(f) top view of $(R)-4 c-2$

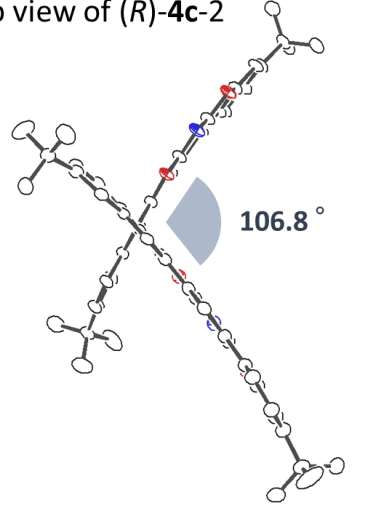

Figure 4: ORTEP drawings of $4 \mathrm{~b}$ and $4 \mathrm{c}$ with $50 \%$ thermal probability. Hydrogen atoms and solvent molecules are omitted for clarity. Only major orientation of the disordered structure is displayed. The CCDC numbers are 1971471 for $(R)-4 \mathbf{b}$ and 1971470 for $(R)-4 \mathbf{c}$.

(a) Stacking of $(R)-\mathbf{4 b}$

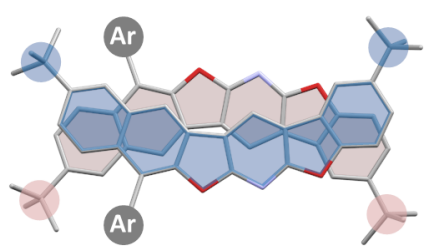

(b) Stacking of $(R)-4 c$

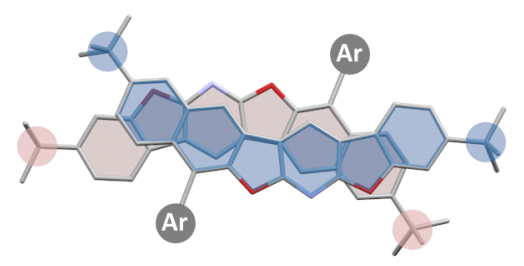

(c) Packing of (R)-4b

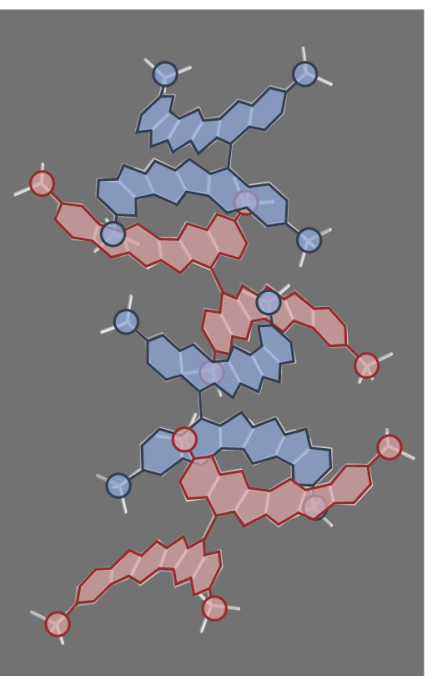

(d) Packing of (R)-4c

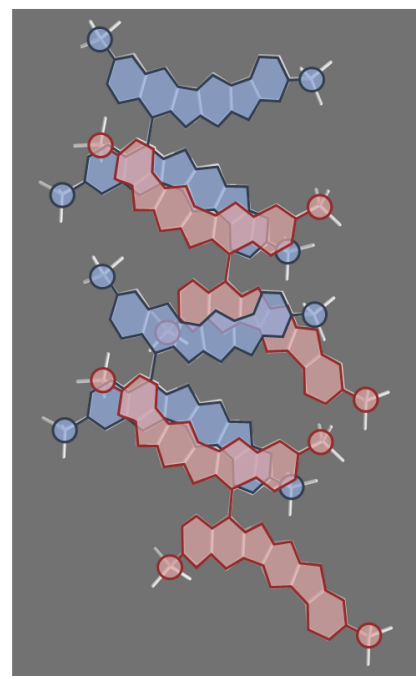

Figure 5: Intramolecular stacking structures of $\mathbf{4 b}$ and $\mathbf{4 c}$

of around $3.45 \AA$. It is noteworthy that both $\mathbf{4 b}$ and $\mathbf{4 c}$ pile up while minimizing the steric repulsion between the tert-butyl groups which occupy "staggered" orientations in their crystal structures (Figure 5c and 5d). Unfortunately, the crystal structure of $4 \mathbf{a}$ was not determined after numerous attempts for obtaining crystals suitable for the X-ray analysis. Based on these 
observations, it is reasonable to conclude that the tert-butyl substituents effectively restricted the stacking structure to the specific conformations, thereby facilitating the assembly of wellordered aggregates in the solid state [50-54].

\section{Conclusion}

In summary, we have achieved the synthesis of a series of CPLactive polyheteroaromatic compounds from readily available chiral BINOLs via the $O$-arylation and subsequent palladiumcatalyzed $\mathrm{C}-\mathrm{H} / \mathrm{C}-\mathrm{H}$ coupling reaction. The substitution pattern on the BBZFPy skeleton had much effect on the solid-state optical properties. Particularly, the compounds $\mathbf{4 b}$ and $\mathbf{4 c}$ bearing terminal tert-butyl groups exhibited solid-state fluorescence with the enhanced CPL characteristics $\left(g_{\text {lum }}=6.68 \times 10^{-3}\right.$ and $6.06 \times 10^{-3}$ ), as compared to those in solution. Their solid-state structures were investigated by X-ray diffraction analysis to find well-ordered intermolecular stacking structures within the crystals.

\section{Experimental General}

All manipulations were performed under $\mathrm{N}_{2}$ using standard Schlenk techniques unless otherwise noted. DMF was dried and deoxygenated by a Glass Counter Solvent Dispending System (Nikko Hansen \& Co., Ltd.). DMSO was distilled from $\mathrm{CaH}_{2}$ and stored over molecular sieves $4 \AA$ A Silica gel column chromatography was performed using Wakosil ${ }^{\circledR}$ C-200 (64-210 $\mu \mathrm{m})$. Nuclear magnetic resonance spectra were measured at $400 \mathrm{MHz}\left({ }^{1} \mathrm{H} \mathrm{NMR}\right)$ and at $100 \mathrm{MHz}\left({ }^{13} \mathrm{C} \mathrm{NMR}\right)$ in $5 \mathrm{~mm}$ NMR tubes. ${ }^{1} \mathrm{H}$ NMR chemical shifts were reported in ppm relative to the resonance of TMS $(\delta 0.00)$ or the residual solvent signals at $\delta 7.26$ for $\mathrm{CDCl}_{3} \cdot{ }^{13} \mathrm{C}$ NMR chemical shifts were reported in ppm relative to the residual solvent signals at $\delta 77.2$ for $\mathrm{CDCl}_{3}$. Melting points were measured using a Mettler Toledo MP90. High-resolution mass spectra (HRMS) were recorded by APCI-TOF or EI. Preparative gel permeation chromatography (GPC) was conducted with a YMC GPCT2000 column eluting with $\mathrm{CHCl}_{3}$. Absorption spectra were recorded with JASCO V-750 spectrometer. Photoluminescence spectra were recorded with JASCO FP-8500 spectrometer. Quantum yield was determined using an integration sphere system. CD and CPL spectra were recorded with JASCO J-820AC and JASCO CPL-300 spectrometers. HPLC analysis was carried out with JASCO EXTREMA (PU4180/MD4015/ CO4065) equipped with YMC CHIRAL ART Amylose-SA and YMC CHIRAL ART Cellulose-SB columns.

\section{Preparation of 6,6'-di-tert-butyl-BINOL (1)}

Compound $1 \mathrm{was}$ prepared according to a literature procedure [55]. ${ }^{1} \mathrm{H}$ NMR (400 MHz, $\left.\mathrm{CDCl}_{3}\right) \delta 1.38(\mathrm{~s}, 18 \mathrm{H}), 4.96(\mathrm{~s}, 2 \mathrm{H})$, $7.13(\mathrm{~d}, J=8.9 \mathrm{~Hz}, 2 \mathrm{H}), 7.36(\mathrm{~d}, J=8.9 \mathrm{~Hz}, 2 \mathrm{H}), 7.41(\mathrm{dd}, J=$
2.0, $8.9 \mathrm{~Hz}, 2 \mathrm{H}), 7.82(\mathrm{~d}, J=2.0 \mathrm{~Hz}, 2 \mathrm{H}), 7.94(\mathrm{~d}, J=8.9 \mathrm{~Hz}$, $2 \mathrm{H}) ;{ }^{13} \mathrm{C} \mathrm{NMR}\left(100 \mathrm{MHz}, \mathrm{CDCl}_{3}\right) \delta 31.25,34.61,110.62$, 117.54, 123.49, 124.01, 126.36, 129.35, 131.34, 131.42, 146.69, 152.29; HRMS-APCI $(\mathrm{m} / \mathrm{z}):[\mathrm{M}+\mathrm{H}]^{+}$calcd for $\mathrm{C}_{28} \mathrm{H}_{31} \mathrm{O}_{2}$, 399.2330; found, 399.2319. The enantiomeric purity was confirmed by HPLC analysis: CHIRAL ART Amylose-SA column, $n$-hexane/2-propanol 90:10, $1.0 \mathrm{~mL} / \mathrm{min}, 40{ }^{\circ} \mathrm{C} ;(S)-\mathbf{1}: t_{\mathrm{R}}=$ $17.9 \min ,(R)-\mathbf{1}: t_{\mathrm{R}}=6.83 \mathrm{~min}, \mathrm{UV}$ detection at $250.0 \mathrm{~nm}$.

\section{Preparation of 2}

To a $20 \mathrm{~mL}$ two-necked round-bottomed flask were added $\mathbf{1}$ (796 mg, $2.0 \mathrm{mmol})$ and $\mathrm{Cs}_{2} \mathrm{CO}_{3}(978 \mathrm{mg}, 6.0 \mathrm{mmol})$. 2,6Difluoropyridine $(0.55 \mathrm{~mL}, 6.0 \mathrm{mmol})$ and DMF $(10 \mathrm{~mL})$ were added via syringe. The mixture was stirred at $40{ }^{\circ} \mathrm{C}$ for $48 \mathrm{~h}$ under $\mathrm{N}_{2}$. The resulting mixture was extracted with EtOAc. The organic layer was washed with water, dried over $\mathrm{Na}_{2} \mathrm{SO}_{4}$, and evaporated in vacuo. The residue was purified by silica gel column chromatography (eluent: hexane/EtOAc 2:1) and GPC to give the title compound as white solid; $(S)-2(1.01 \mathrm{~g}, 86 \%$ yield), (R)-2 (1.06 g, 90\% yield). Mp 212-214 ${ }^{\circ} \mathrm{C} ;{ }^{1} \mathrm{H}$ NMR $\left(400 \mathrm{MHz}, \mathrm{CDCl}_{3}\right) \delta 1.37(\mathrm{~s}, 18 \mathrm{H}), 6.28(\mathrm{dd}, J=2.6,7.8 \mathrm{~Hz}$, $2 \mathrm{H}), 6.37(\mathrm{dd}, J=1.2,8.0 \mathrm{~Hz}, 2 \mathrm{H}), 7.20(\mathrm{~d}, J=0.8 \mathrm{~Hz}, 2 \mathrm{H})$, $7.33(\mathrm{~d}, J=8.8 \mathrm{~Hz}, 2 \mathrm{H}), 7.34(\mathrm{~d}, J=8.8 \mathrm{~Hz}, 2 \mathrm{H}), 7.39(\mathrm{dd}, J=$ 2.0, $8.4 \mathrm{~Hz}, 2 \mathrm{H}), 7.77(\mathrm{~d}, J=2.0 \mathrm{~Hz}, 2 \mathrm{H}), 7.89(\mathrm{~d}, J=8.8 \mathrm{~Hz}$, $2 \mathrm{H}) ;{ }^{13} \mathrm{C} \mathrm{NMR}\left(100 \mathrm{MHz}, \mathrm{CDCl}_{3}\right) \delta 31.18,34.68,101.52$, 101.87, 121.38, 122.81, 123.20, 125.29, 126.12, 129.51, 131.09, $131.96,142.60\left(\mathrm{~d}, J_{\mathrm{C}-\mathrm{F}}=7.8 \mathrm{~Hz}\right), 147.89,148.95,161.61(\mathrm{~d}$, $\left.J_{\mathrm{C}-\mathrm{F}}=14.0 \mathrm{~Hz}\right), 162.28\left(\mathrm{~d}, J_{\mathrm{C}-\mathrm{F}}=240 \mathrm{~Hz}\right),{ }^{19} \mathrm{~F} \mathrm{NMR}$ $\left(376 \mathrm{MHz}, \mathrm{CDCl}_{3}\right) \delta$ 69.06; HRMS-APCI $(\mathrm{m} / \mathrm{z}):[\mathrm{M}+\mathrm{H}]^{+}$ calcd for $\mathrm{C}_{38} \mathrm{H}_{35} \mathrm{~F}_{2} \mathrm{~N}_{2} \mathrm{O}_{2}$, 589.2644; found, 589.2661. The enantiomeric purity was confirmed by HPLC analysis: CHIRAL ART Cellulose-SB column, $n$-hexane/chloroform 95:5, $1.0 \mathrm{~mL} / \mathrm{min}, 40{ }^{\circ} \mathrm{C} ;(S)-2: t_{\mathrm{R}}=9.86 \mathrm{~min},(R)-2: t_{\mathrm{R}}=$ $21.29 \mathrm{~min}, \mathrm{UV}$ detection at $250.0 \mathrm{~nm}$.

\section{Preparation of $\mathbf{3 a - c}$}

Compound 3a: To a $10 \mathrm{~mL}$ Schlenk flask were added 2 (294 mg, $0.5 \mathrm{mmol}$ ), phenol (103 mg, $1.1 \mathrm{mmol}$ ), and $\mathrm{Cs}_{2} \mathrm{CO}_{3}$ (358 $\mathrm{mg}, 1.1 \mathrm{mmol})$. DMSO $(3.5 \mathrm{~mL})$ was added via the syringe. The mixture was stirred at $100{ }^{\circ} \mathrm{C}$ for $18 \mathrm{~h}$ under $\mathrm{N}_{2}$. The resulting mixture was extracted with EtOAc. The organic layer was washed with water, dried over $\mathrm{Na}_{2} \mathrm{SO}_{4}$, and evaporated in vacuo. The residue was purified by silica gel column chromatography (eluent: hexane/EtOAc 6:1) and GPC to give the title compound as white solid; $(S)$-3a (309 mg, 84\% yield), $(R)$ 3a (332 mg, 90\%). Mp 110-112 ${ }^{\circ} \mathrm{C}$; ${ }^{1} \mathrm{H}$ NMR (400 MHz, $\left.\mathrm{CDCl}_{3}\right) \delta 1.29(\mathrm{~s}, 18 \mathrm{H}), 6.10(\mathrm{~d}, J=7.9 \mathrm{~Hz}, 2 \mathrm{H}), 6.16(\mathrm{~d}, J=$ $7.9 \mathrm{~Hz}, 2 \mathrm{H}), 6.91$ (dd, $J=0.92,8.5 \mathrm{~Hz}, 4 \mathrm{H}), 6.99-7.03$ (m, 4H), $7.14-7.17(\mathrm{~m}, 8 \mathrm{H}), 7.22(\mathrm{~d}, J=8.8 \mathrm{~Hz}, 2 \mathrm{H}), 7.68(\mathrm{~d}, J=2.0 \mathrm{~Hz}$, 2H), $7.73(\mathrm{~d}, J=8.8 \mathrm{~Hz}, 2 \mathrm{H}) ;{ }^{13} \mathrm{C} \mathrm{NMR}\left(100 \mathrm{MHz} \mathrm{CDCl}_{3}\right) \delta$ $31.23,34.63,103.72,104.83,121.03,121.55,122.67,123.15$, 
124.27, 125.03, 126.13, 129.10, 129.30, 130.90, 132.04, 141.35, 147.49, 149.54, 154.00, 161.86, 162.48; HRMS-APCI $(\mathrm{m} / \mathrm{z})$ : $[\mathrm{M}+\mathrm{H}]^{+}$calcd for $\mathrm{C}_{50} \mathrm{H}_{45} \mathrm{~N}_{2} \mathrm{O}_{4}, 737.3367$; found, 737.3374. The enantiomeric purity was confirmed by HPLC analysis: CHIRAL ART Amylose-SA column, $n$-hexane/chloroform 95:5, $1.0 \mathrm{~mL} / \mathrm{min}, 40{ }^{\circ} \mathrm{C}$; $(S)-3 \mathbf{a}: t_{\mathrm{R}}=7.25 \mathrm{~min},(R)-\mathbf{3 a}: t_{\mathrm{R}}=$ $14.12 \mathrm{~min}$, UV detection at $250.0 \mathrm{~nm}$.

Compound 3b: Synthesized similarly to 3a using 4-tertbutylphenol. Purified by silica gel column chromatography (eluent: hexane/EtOAc 4:1) and GPC to give the title compound as white solid; $(S)$-3b (399 $\mathrm{mg}, 94 \%$ yield), $(R)-\mathbf{3 b}$ (386 mg, 91\% yield). Mp 113-115 ${ }^{\circ} \mathrm{C} ;{ }^{1} \mathrm{H}$ NMR (400 MHz, $\left.\mathrm{CDCl}_{3}\right) \delta 1.16(\mathrm{~s}, 18 \mathrm{H}), 1.35(\mathrm{~s}, 18 \mathrm{H}), 6.20(\mathrm{~d}, J=8.0 \mathrm{~Hz}, 2 \mathrm{H})$, $6.28(\mathrm{~d}, J=7.6 \mathrm{~Hz}, 2 \mathrm{H}), 6.77(\mathrm{~d}, J=8.9 \mathrm{~Hz}, 2 \mathrm{H}), 6.88(\mathrm{dd}, J=$ 2.1, $6.7 \mathrm{~Hz}, 4 \mathrm{H}), 7.09(\mathrm{dd}, J=2.0,8.0 \mathrm{~Hz}, 2 \mathrm{H}), 7.12(\mathrm{dd}, J=$ 2.1, 7.0 Hz, 4H), $7.23(\mathrm{~d}, J=8.8 \mathrm{~Hz}, 2 \mathrm{H}), 7.29$ (t, $J=8.0 \mathrm{~Hz}$, $2 \mathrm{H}), 7.72(\mathrm{~d}, J=2.0 \mathrm{~Hz}, 2 \mathrm{H}), 7.78(\mathrm{~d}, J=8.8 \mathrm{~Hz}, 2 \mathrm{H})$; ${ }^{13} \mathrm{C}$ NMR $\left(100 \mathrm{MHz}, \mathrm{CDCl}_{3}\right) \delta 31.23,31.95,34.22,34.58$, $103.43,104.29,120.83,121.94,122.40,123.40,125.01,125.73$, 126.23, 128.83, 130.79, 132.05, 141.29, 146.89, 147.26, 149.60, 151.15, 161.82, 162.41; HRMS-APCI $(\mathrm{m} / \mathrm{z}):[\mathrm{M}+\mathrm{H}]^{+}$calcd for $\mathrm{C}_{58} \mathrm{H}_{61} \mathrm{~N}_{2} \mathrm{O}_{4}, 849.4603$; found, 849.4626. The enantiomeric purity was confirmed by HPLC analysis: CHIRAL ART Amylose-SA column, $n$-hexane/chloroform 95:5, $1.0 \mathrm{~mL} / \mathrm{min}, 40{ }^{\circ} \mathrm{C} ;(S)-\mathbf{3 b}: t_{\mathrm{R}}=8.36 \mathrm{~min},(R)-\mathbf{3 b}: t_{\mathrm{R}}=10.05$ min, $\mathrm{UV}$ detection at $250.0 \mathrm{~nm}$.

Compound 3c: Synthesized similarly to 3a using 3-tertbutylphenol. Purified by silica gel column chromatography (eluent: hexane/EtOAc 6:1) and GPC to give the title compound as white solid; $(S)-3 \mathbf{c}(377 \mathrm{mg}, 89 \%$ yield), $(R)-\mathbf{3 c}$ (403 mg, 95\% yield). Mp 88-90 ${ }^{\circ} \mathrm{C} ;{ }^{1} \mathrm{H}$ NMR (400 MHz, $\left.\mathrm{CDCl}_{3}\right) \delta 1.17(\mathrm{~s}, 18 \mathrm{H}), 1.36(\mathrm{~s}, 18 \mathrm{H}), 6.14(\mathrm{~d}, J=8.0 \mathrm{~Hz}, 2 \mathrm{H})$, $6.23(\mathrm{~d}, J=7.6 \mathrm{~Hz}, 2 \mathrm{H}), 6.79(\mathrm{ddd}, J=1.0,2.2,7.3 \mathrm{~Hz}, 2 \mathrm{H})$, $7.02(\mathrm{t}, J=2.0 \mathrm{~Hz}, 2 \mathrm{H}), 7.09-7.13(\mathrm{~m}, 4 \mathrm{H}), 7.16-7.28(\mathrm{~m}, 8 \mathrm{H})$, $7.73(\mathrm{~d}, J=1.6 \mathrm{~Hz}, 2 \mathrm{H}), 7.76(\mathrm{~d}, J=8.8 \mathrm{~Hz}, 2 \mathrm{H}) ;{ }^{13} \mathrm{C} \mathrm{NMR}$ $\left(100 \mathrm{MHz}, \mathrm{CDCl}_{3}\right) \delta 31.16,31.22,34.61,34.63,103.53$, 104.62, 117.99, 118.29, 121.39, 121.53, 122.67, 123.11, 124.94, $126.13,128.82$, 129.06, 130.86, 132.03, 141.26, 147.42, 149.48, 153.01, 153.87, 162.23, 162.50; HRMS-APCI $(\mathrm{m} / \mathrm{z}):[\mathrm{M}+\mathrm{H}]^{+}$ calcd for $\mathrm{C}_{58} \mathrm{H}_{61} \mathrm{~N}_{2} \mathrm{O}_{4}, 849.4599$; found, 849.4626. The enantiomeric purity was confirmed by HPLC analysis: CHIRAL ART Amylose-SA column, $n$-hexane/chloroform 95:5, $1.0 \mathrm{~mL} / \mathrm{min}, 40^{\circ} \mathrm{C} ;(S)-3 \mathbf{c}: t_{\mathrm{R}}=9.00 \mathrm{~min},(R)-3 \mathbf{c}: t_{\mathrm{R}}=8.61 \mathrm{~min}$ $\mathrm{UV}$ detection at $250.0 \mathrm{~nm}$.

\section{Preparation of $4 \mathbf{a}-\mathbf{c}$}

Compound 4a: To a $10 \mathrm{~mL}$ Schlenk flask were added 3a (184 mg, $0.25 \mathrm{mmol}), \mathrm{Pd}(\mathrm{TFA})_{2}(24.9 \mathrm{mg}, 0.075 \mathrm{mmol})$ $\mathrm{AgOAc}(167 \mathrm{mg}, 1.0 \mathrm{mmol})$, and $\mathrm{PivOH}(2.0 \mathrm{~mL})$. The mix- ture was heated at $150{ }^{\circ} \mathrm{C}$ for $24 \mathrm{~h}$ under air. After cooling to room temperature, the resulting mixture was diluted with water and filtered through a pad of Celite eluting with dichloromethane. The filtrate was washed with water, dried over $\mathrm{Na}_{2} \mathrm{SO}_{4}$, and concentrated in vacuo. The obtained crude material was again subjected to the catalytic conditions described above. The residue was purified by silica gel column chromatography (eluent: hexane/dichloromethane 4:1) and GPC to give the title compound as pale yellow solid; $(S)-4 a$ a $(28.2 \mathrm{mg}, 16 \%$ yield), $(R)-\mathbf{4 a}\left(18.1 \mathrm{mg}, 10 \%\right.$ yield). $\mathrm{Mp}>300{ }^{\circ} \mathrm{C} ;{ }^{1} \mathrm{H}$ NMR $\left(400 \mathrm{MHz}, \mathrm{CDCl}_{3}\right) \delta 1.46(\mathrm{~s}, 18 \mathrm{H}), 7.44-7.52(\mathrm{~m}, 8 \mathrm{H}), 7.62(\mathrm{~d}$, $J=8.0 \mathrm{~Hz}, 2 \mathrm{H}), 8.07(\mathrm{dd}, J=0.8,7.6 \mathrm{~Hz}, 2 \mathrm{H}), 8.12(\mathrm{~d}, J=$ $2.0 \mathrm{~Hz}, 2 \mathrm{H}), 8.67(\mathrm{~s}, 2 \mathrm{H}), 8.96(\mathrm{~s}, 2 \mathrm{H}) ;{ }^{13} \mathrm{C} \mathrm{NMR}(100 \mathrm{MHz}$, $\left.\mathrm{CDCl}_{3}\right) \delta 31.25,34.82,112.20,112.62,113.07,113.65,120.13$, $120.59,122.80,122.93,123.21,123.61,123.62,125.68,125.81$, $127.39,130.67,130.90,147.553,151.62,154.63,161.90$, 163.10; HRMS-APCI $(\mathrm{m} / \mathrm{z})$ : $[\mathrm{M}+\mathrm{H}]^{+}$calcd for $\mathrm{C}_{50} \mathrm{H}_{37} \mathrm{~N}_{2} \mathrm{O}_{4}$, 729.2723; found, 729.2748. The enantiomeric purity was determined by HPLC analysis: CHIRAL ART Amylose-SA column, $n$-hexane/chloroform 60:40, $1.0 \mathrm{~mL} / \mathrm{min}, 40{ }^{\circ} \mathrm{C} ;(S)-\mathbf{4 a}: t_{\mathrm{R}}=$ $4.39 \min ,(R)-4 a: t_{\mathrm{R}}=6.73 \mathrm{~min}$, UV detection at $250.0 \mathrm{~nm}$.

Compound 4b: Synthesized similarly to $4 \mathbf{b}$ from $3 \mathbf{b}$ (254 mg, $0.30 \mathrm{mmol}$ ). Purified by silica gel column chromatography (eluent: hexane/EtOAc 4:1) and GPC to give the title compound as pale yellow solid; $(S)-\mathbf{4 b}$ (45.4 mg, 18\% yield), $(R)-\mathbf{4 b}$ (30.2 mg, 12\% yield). Single crystals suitable for the X-ray analysis were obtained by slow evaporation from EtOAc solution. $\mathrm{Mp}>300{ }^{\circ} \mathrm{C} ;{ }^{1} \mathrm{H}$ NMR $\left(400 \mathrm{MHz}, \mathrm{CDCl}_{3}\right) \delta 1.46(\mathrm{~s}, 18 \mathrm{H})$, $1.48(\mathrm{~s}, 18 \mathrm{H}), 7.47-7.71(\mathrm{~m}, 8 \mathrm{H}), 8.07$ (d, $J=0.8 \mathrm{~Hz}, 2 \mathrm{H}), 8.11$ $(\mathrm{d}, J=1.6 \mathrm{~Hz}, 2 \mathrm{H}), 8.65(\mathrm{~s}, 2 \mathrm{H}), 8.98(\mathrm{~s}, 2 \mathrm{H}) ;{ }^{13} \mathrm{C} \mathrm{NMR}$ $\left(100 \mathrm{MHz}, \mathrm{CDCl}_{3}\right) \delta 31.26,31.87,34.82,34.98,111.49$, 112.62, 113.40, 113.47, 116.98, 119.97, 122.31, 122.75, 122.35, 123.57, 125.13, 125.69, 125.73, 130.64, 130.87, 146.82, 147.48, 151.62, 152.78, 162.25, 162.94; HRMS-EI $(\mathrm{m} / \mathrm{z}):[\mathrm{M}]^{+}$calcd for $\mathrm{C}_{58} \mathrm{H}_{52} \mathrm{~N}_{2} \mathrm{O}_{4}, 840.3927$; found, 840.3932; $[\alpha]_{D}^{20}=+31.8$ ( $S$-isomer), -32.4 ( $R$-isomer) as $\mathrm{CHCl}_{3}$ solution. The enantiomeric purity was determined by HPLC analysis: CHIRAL ART Amylose-SA column, $n$-hexane/2-propanol 90:10, $1.0 \mathrm{~mL} / \mathrm{min}, 40{ }^{\circ} \mathrm{C} ;(S)-\mathbf{4 b}: t_{\mathrm{R}}=15.95 \mathrm{~min},(R)-\mathbf{4 b}: t_{\mathrm{R}}=24.38$ min, UV detection at $250.0 \mathrm{~nm}$.

Compound 4c: Synthesized similarly to 4c from 3c (254 mg, $0.3 \mathrm{mmol}$ ). Purified by silica gel column chromatography (eluent: hexane/EtOAc 4:1) and GPC to give the title compound as pale yellow solid; $(S)-\mathbf{4 c}(74.1 \mathrm{mg}, 29 \%$ yield), $(R)-\mathbf{4 c}$ ( $90.0 \mathrm{mg}, 36 \%$ yield). Single crystals suitable for the $\mathrm{X}$-ray analysis were obtained by hexane vapor diffusion into $\mathrm{CHCl}_{3}$ solution. $\mathrm{Mp}>300{ }^{\circ} \mathrm{C} ;{ }^{1} \mathrm{H} \mathrm{NMR}\left(400 \mathrm{MHz}, \mathrm{CDCl}_{3}\right) \delta 1.41$ (s, $18 \mathrm{H}), 1.45(\mathrm{~s}, 18 \mathrm{H}), 7.47-7.64(\mathrm{~m}, 6 \mathrm{H}), 7.637$ (d, $J=0.8 \mathrm{~Hz}$, 2H), $7.97(\mathrm{~d}, J=8.4 \mathrm{~Hz}, 2 \mathrm{H}), 8.10(\mathrm{~d}, J=0.8 \mathrm{~Hz}, 2 \mathrm{H}), 8.65$ (s, 
2H), $8.91(\mathrm{~s}, 2 \mathrm{H}) ;{ }^{13} \mathrm{C} \mathrm{NMR}\left(100 \mathrm{MHz}, \mathrm{CDCl}_{3}\right) \delta 31.26,31.57$, 34.81, 3.38, 109.04, 112.62, 113.23, 113.39, 119.98, 119.99, $120.05,121.20,122.53,123.35,123.58,125.69,125.70,130.63$, $130.88,147.46,151.62,151.76,155.05,162.12,162.77$; HRMS-APCI $(m / z):[\mathrm{M}+\mathrm{H}]^{+}$calcd for $\mathrm{C}_{58} \mathrm{H}_{53} \mathrm{~N}_{2} \mathrm{O}_{4}$, 841.3970; found, 841.4000. The enantiomeric purity was determined by HPLC analysis: CHIRAL ART Amylose-SA column, $n$-hexane/chloroform 70:30, $1.0 \mathrm{~mL} / \mathrm{min}, 40{ }^{\circ} \mathrm{C} ;(S)-\mathbf{4 c}: t_{\mathrm{R}}=$ $4.48 \min ,(R)-4 \mathrm{c}: t_{\mathrm{R}}=6.66 \mathrm{~min}$, $\mathrm{UV}$ detection at $250.0 \mathrm{~nm}$.

\section{Preparation of $\mathbf{5}$}

In a $200 \mathrm{~mL}$ three-necked round-bottomed flask, 1 (1.99 g, $5.0 \mathrm{mmol})$ was added to a suspension of $t$-BuOK $(1.40 \mathrm{~g}$, $12.5 \mathrm{mmol})$ in THF $(80 \mathrm{~mL})$ at $0{ }^{\circ} \mathrm{C}$. After stirring for $2 \mathrm{~h}$, $\mathrm{Ph}_{2}$ IOTf (5.38 g, $\left.12.5 \mathrm{mmol}\right)$ was added in one portion. The mixture was allowed to warm to $40{ }^{\circ} \mathrm{C}$, and stirred at this temperature until the complete consumption 1 was confirmed by TLC. The resulting suspension was poured into ice water and extracted with $\mathrm{Et}_{2} \mathrm{O}$. The combined organic layer was dried over $\mathrm{Na}_{2} \mathrm{SO}_{4}$ and concentrated in vacuo. The residue was purified by silica gel column chromatography (eluent: hexane/ EtOAc 20:1) and GPC $\left(\mathrm{CHCl}_{3}\right)$ to give the title compound as white solid; $(S)-5$ (1.59 g, 58\% yield), $(R)-5(1.71 \mathrm{~g}, 62 \%$ yield). Mp 167.0-169.0 ${ }^{\circ} \mathrm{C} ;{ }^{1} \mathrm{H}$ NMR (400 MHz, $\left.\mathrm{CDCl}_{3}\right) \delta 1.39$ (s, 18H), 6.79 (d, $J=7.6, \mathrm{~Hz}, 4 \mathrm{H}), 6.92(\mathrm{t}, J=7.6 \mathrm{~Hz}, 2 \mathrm{H}), 7.10$ (t, $J=7.6 \mathrm{~Hz}, 4 \mathrm{H}), 7.17(\mathrm{~d}, J=8.9 \mathrm{~Hz}, 2 \mathrm{H}), 7.27(\mathrm{~d}, J=9.2 \mathrm{~Hz}$, $2 \mathrm{H}), 7.39(\mathrm{dd}, J=2.0,8.9 \mathrm{~Hz}, 2 \mathrm{H}), 7.79(\mathrm{~d}, J=1.7 \mathrm{~Hz}, 2 \mathrm{H})$, $7.83(\mathrm{~d}, J=8.9 \mathrm{~Hz}, 2 \mathrm{H}) ;{ }^{13} \mathrm{C} \mathrm{NMR}\left(100 \mathrm{MHz}, \mathrm{CDCl}_{3}\right) \delta 31.25$, $34.65,118.84,119.29,122.06,122.43,123.04,125.46,125.63$, $129.19129 .46,130.30,132.44,147.18,152.08,157.74$; HRMS-APCI $[\mathrm{m} / \mathrm{z}]:[\mathrm{M}+\mathrm{H}]^{+}$calcd for $\mathrm{C}_{40} \mathrm{H}_{39} \mathrm{O}_{2}, 551.2959$; found, 551.2945. The enantiomeric purity was confirmed by HPLC analysis: CHIRAL ART Amylose-SA column, $n$-hexane/ chloroform 98:2, $1.0 \mathrm{~mL} / \mathrm{min}, 40{ }^{\circ} \mathrm{C} ;(S)-5: t_{\mathrm{R}}=4.91 \mathrm{~min}$, $(R)-5: t_{\mathrm{R}}=5.32 \mathrm{~min}$, UV detection at $250.0 \mathrm{~nm}$.

\section{Preparation of 6}

To a $10 \mathrm{~mL}$ Schlenk flask were added $5(165 \mathrm{mg}, 0.3 \mathrm{mmol})$, Pd(TFA) 2 (29.9 mg, $0.09 \mathrm{mmol})$, AgOAc (198 mg, $1.2 \mathrm{mmol})$, and $\mathrm{PivOH}(3.0 \mathrm{~mL})$. The mixture was heated at $150{ }^{\circ} \mathrm{C}$ for $24 \mathrm{~h}$ under air. After cooling to room temperature, the resulting mixture was diluted with water and filtered through a pad of Celite eluting with dichloromethane. The filtrate was washed with water, dried over $\mathrm{Na}_{2} \mathrm{SO}_{4}$, and concentrated in vacuo. The residue was purified by silica gel column chromatography (eluent: hexane/EtOAc 2:1) and GPC to give the title compound as pale yellow solid; $(S)-6(30.1 \mathrm{mg}, 18 \%$ yield), $(R)-6$ (30.3 mg, 18\% yield). Mp 212-214 ${ }^{\circ} \mathrm{C} ;{ }^{1} \mathrm{H}$ NMR (400 MHz, $\left.\mathrm{CDCl}_{3}\right) \delta 1.41(\mathrm{~s}, 18 \mathrm{H}), 7.31(\mathrm{dd}, J=0.8,7.6 \mathrm{~Hz}, 2 \mathrm{H}), 7.35(\mathrm{dd}$, $J=1.2,7.6 \mathrm{~Hz}, 2 \mathrm{H}), 7.38-7.43(\mathrm{~m}, 6 \mathrm{H}), 8.09$ (s, 2H), 8.13-8.16 $(\mathrm{m}, 2 \mathrm{H}), 8.61(\mathrm{~s}, 2 \mathrm{H}) ;{ }^{13} \mathrm{C} \mathrm{NMR}\left(100 \mathrm{MHz}, \mathrm{CDCl}_{3}\right) \delta 31.26$,
$34.74,111.88,112.25,119.71,121.16,122.62,123.61,124.35$, 125.08, 125.26, 125.55, 128.08, 130.54, 130.75, 146.80, 153.36, 157.70; HRMS-APCI $(\mathrm{m} / \mathrm{z}):[\mathrm{M}+\mathrm{H}]^{+}$calcd for $\mathrm{C}_{40} \mathrm{H}_{35} \mathrm{O}_{2}$, 547.2622; found, 547.2632. The enantiomeric purity was confirmed by HPLC analysis: CHIRAL ART Amylose-SA column, $n$-hexane/EtOAc 95:5, $1.0 \mathrm{~mL} / \mathrm{min}, 40{ }^{\circ} \mathrm{C} ;(S)-6: t_{\mathrm{R}}=6.47 \mathrm{~min}$, $(R)-6: t_{\mathrm{R}}=6.24 \mathrm{~min}, \mathrm{UV}$ detection at $250.0 \mathrm{~nm}$.

\section{Supporting Information}

\section{Supporting Information File 1}

Summary of X-ray crystallography data, copy of NMR spectra, and copy of HPLC charts.

[https://www.beilstein-journals.org/bjoc/content/ supplementary/1860-5397-16-32-S1.pdf]

\section{Funding}

This work was supported by JSPS KAKENHI Grant No. JP 19K15586 (Grant-in-Aid for Young Scientists) to Y.N. and JP 17H06092 (Grant-in-Aid for Specially Promoted Research) to M.M.

\section{ORCID ${ }^{\circledR}$ iDs}

Yuji Nishii - https://orcid.org/0000-0002-6824-0639

Masahiro Miura - https://orcid.org/0000-0001-8288-6439

\section{References}

1. Yang, Y.; Lan, J.; You, J. Chem. Rev. 2017, 117, 8787-8863. doi:10.1021/acs.chemrev.6b00567

See for a recent review on the oxidative coupling.

2. Yoshimoto, H.; Itatani, H. Bull. Chem. Soc. Jpn. 1973, 46, 2490-2492. doi:10.1246/bcsj.46.2490

3. Shiotani, A.; Itatani, H. Angew. Chem., Int. Ed. Engl. 1974, 13, 471-472. doi:10.1002/anie.197404711

4. Åkermark, B.; Eberson, L.; Jonsson, E.; Pettersson, E. J. Org. Chem. 1975, 40, 1365-1367. doi:10.1021/jo00897a048

5. Knölker, H.-J.; O'Sullivan, N. Tetrahedron 1994, 50, 10893-10908. doi:10.1016/s0040-4020(01)85701-x

6. Åkermark, B.; Oslob, J. D.; Heuschert, U. Tetrahedron Lett. 1995, 36, 1325-1326. doi:10.1016/0040-4039(94)02467-p

7. Hagelin, H.; Oslob, J. D.; Åkermark, B. Chem. - Eur. J. 1999, 5, 2413-2416.

doi:10.1002/(sici)1521-3765(19990802)5:8<2413::aid-chem2413>3.0.c $0 ; 2-3$

8. Knölker, H.-J.; Fröhner, W.; Reddy, K. R. Synthesis 2002, 557-564. doi:10.1055/s-2002-20953

9. Matsubara, S.; Asano, K.; Kajita, Y.; Yamamoto, M. Synthesis 2007, 2055-2059. doi:10.1055/s-2007-983738

10. Watanabe, T.; Ueda, S.; Inuki, S.; Oishi, S.; Fujii, N.; Ohno, H. Chem. Commun. 2007, 4516-4518. doi:10.1039/b707899d

11. Liegault, B.; Lee, D.; Huestis, M. P.; Stuart, D. R.; Fagnou, K. J. Org. Chem. 2008, 73, 5022-5028. doi:10.1021/j0800596m

12. Kaida, H.; Satoh, T.; Hirano, K.; Miura, M. Chem. Lett. 2015, 44, 1125-1127. doi:10.1246/cl.150408 
13. Kaida, H.; Satoh, T.; Nishii, Y.; Hirano, K.; Miura, M. Chem. Lett. 2016, 45, 1069-1071. doi:10.1246/cl.160496

14. Kaida, H.; Goya, T.; Nishii, Y.; Hirano, K.; Satoh, T.; Miura, M. Org. Lett. 2017, 19, 1236-1239. doi:10.1021/acs.orglett.7b00323

15. Itai, Y.; Nishii, Y.; Stachelek, P.; Data, P.; Takeda, Y.; Minakata, S.; Miura, M. J. Org. Chem. 2018, 83, 10289-10302. doi:10.1021/acs.joc.8b01451

16. Nakamura, S.; Tohnai, N.; Nishii, Y.; Hinoue, T.; Miura, M. ChemPhotoChem 2019, 3, 46-53. doi:10.1002/cptc.201800189

17. Nakamura, S.; Okamoto, M.; Tohnai, N.; Nakayama, K.-i.; Nishii, Y.; Miura, M. Bull. Chem. Soc. Jpn. 2020, 93, 99-108. doi:10.1246/bcsj.20190269

18. Sánchez-Carnerero, E. M.; Agarrabeitia, A. R.; Moreno, F.; Maroto, B. L.; Muller, G.; Ortiz, M. J.; de la Moya, S. Chem. - Eur. J. 2015, 21, 13488-13500. doi:10.1002/chem.201501178

19. Tanaka, H.; Inoue, Y.; Mori, T. ChemPhotoChem 2018, 2, 386-402. doi:10.1002/cptc.201800015

20. Chen, N.; Yan, B. Molecules 2018, 23, 3376. doi:10.3390/molecules23123376

21. Ma, J.-L.; Peng, Q.; Zhao, C.-H. Chem. - Eur. J. 2019, 25 , 15441-15454. doi:10.1002/chem.201903252

22. Schadt, M. Annu. Rev. Mater. Sci. 1997, 27, 305-379. doi:10.1146/annurev.matsci.27.1.305

23. Sherson, J. F.; Krauter, H.; Olsson, R. K.; Julsgaard, B.; Hammerer, K.; Cirac, I.; Polzik, E. S. Nature 2006, 443, 557-560. doi:10.1038/nature05136

24. Feringa, B. L. Acc. Chem. Res. 2001, 34, 504-513. doi:10.1021/ar0001721

25. Kawai, T.; Kawamura, K.; Tsumatori, H.; Ishikawa, M.; Naito, M.; Fujiki, M.; Nakashima, T. ChemPhysChem 2007, 8, 1465-1468. doi:10.1002/cphc.200600747

26. Amako, T.; Kimoto, T.; Tajima, N.; Fujiki, M.; Imai, Y. Tetrahedron 2013, 69, 2753-2757. doi:10.1016/j.tet.2013.01.084

27. Nakabayashi, K.; Amako, T.; Tajima, N.; Fujiki, M.; Imai, Y. Chem. Commun. 2014, 50, 13228-13230. doi:10.1039/c4cc02946a

28. Feuillastre, S.; Pauton, M.; Gao, L.; Desmarchelier, A.; Riives, A. J.; Prim, D.; Tondelier, D.; Geffroy, B.; Muller, G.; Clavier, G.; Pieters, G. J. Am. Chem. Soc. 2016, 138, 3990-3993. doi:10.1021/jacs.6b00850

29. Kitatobe, T.; Mimura, Y.; Tsujimoto, S.; Tajima, N.; Fujiki, M.; Imai, Y. Tetrahedron 2017, 73, 6856-6862. doi:10.1016/j.tet.2017.10.036

30. Zhang, X.; Zhang, Y.; Li, Y.; Quan, Y.; Cheng, Y.; Li, Y. Chem. Commun. 2019, 55, 9845-9848. doi:10.1039/c9cc04289j

31. Zhang, X.; Zhang, Y.; Zhang, H.; Quan, Y.; Li, Y.; Cheng, Y.; Ye, S. Org. Lett. 2019, 21, 439-443. doi:10.1021/acs.orglett.8b03620

32. Wu, Z.-G.; Han, H.-B.; Yan, Z.-P.; Luo, X.-F.; Wang, Y.; Zheng, Y.-X.; Zuo, J.-L.; Pan, Y. Adv. Mater. (Weinheim, Ger.) 2019, 31, 1900524. doi:10.1002/adma.201900524

33. Hassan, K.; Yamashita, K.-i.; Hirabayashi, K.; Shimizu, T.; Nakabayashi, K.; Imai, Y.; Matsumoto, T.; Yamano, A.; Sugiura, K.-i. Chem. Lett. 2015, 44, 1607-1609. doi:10.1246/cl.150704

34. Takaishi, K.; Yamamoto, T.; Hinoide, S.; Ema, T. Chem. - Eur. J. 2017, 23, 9249-9252. doi:10.1002/chem.201702143

35. Takaishi, K.; Takehana, R.; Ema, T. Chem. Commun. 2018, 54, 1449-1452. doi:10.1039/c7cc09187g

36. Takaishi, K.; Iwachido, K.; Takehana, R.; Uchiyama, M.; Ema, T. J. Am. Chem. Soc. 2019, 141, 6185-6190. doi:10.1021/jacs.9b02582

37. Droz, A. S.; Neidlein, U.; Anderson, S.; Seiler, P.; Diederich, F. Helv. Chim. Acta 2001, 84, 2243-2289.

doi:10.1002/1522-2675(20010815)84:8<2243::aid-hlca2243>3.0.co;2-g
38. Ye, P.; Li, Q.; Bai, Z.; Dong, K.; Liu, Q. Heterocycles 2015, 91, 1986-1995. doi:10.3987/com-15-13302

39. Octa-Smolin, F.; van der Vight, F.; Yadav, R.; Bhangu, J.; Soloviova, K.; Wölper, C.; Daniliuc, C. G.; Strassert, C. A.; Somnitz, H.; Jansen, G.; Niemeyer, J. J. Org. Chem. 2018, 83, 14568-14587. doi:10.1021/acs.joc.8b02353

40. Meca, L.; Řeha, D.; Havlas, Z. J. Org. Chem. 2003, 68, 5677-5680. doi:10.1021/j0034344u

41. Moustafa, G. A. I.; Oki, Y.; Akai, S. Angew. Chem., Int. Ed. 2018, 57, 10278-10282. doi:10.1002/anie.201804161

42. Paul, A.; Kumar, A.; Nanjunda, R.; Farahat, A. A.; Boykin, D. W.; Wilson, W. D. Org. Biomol. Chem. 2017, 15, 827-835. doi:10.1039/c6ob02390h

43. Jalalian, N.; Ishikawa, E. E.; Silva, L. F., Jr.; Olofsson, B. Org. Lett. 2011, 13, 1552-1555. doi:10.1021/ol200265t

44. Jalalian, N.; Petersen, T. B.; Olofsson, B. Chem. - Eur. J. 2012, 18, 14140-14149. doi:10.1002/chem.201201645

45. Sperotto, E.; de Vries, J. G.; van Klink, G. P. M.; van Koten, G. Tetrahedron Lett. 2007, 48, 7366-7370. doi:10.1016/j.tetlet.2007.08.026

46. Liu, X.; Zhang, S. Synlett 2011, 268-272. doi:10.1055/s-0030-1259291

47. Kimoto, T.; Tajima, N.; Fujiki, M.; Imai, Y. Chem. - Asian J. 2012, 7, 2836-2841. doi:10.1002/asia.201200725

48. Emeis, C. A.; Oosterhoff, L. J. J. Chem. Phys. 1971, 54, 4809-4819. doi:10.1063/1.1674756

49. Tsumatori, H.; Nakashima, T.; Kawai, T. Org. Lett. 2010, 12 , 2362-2365. doi:10.1021/ol100701w

50. Schweicher, G.; Lemaur, V.; Niebel, C.; Ruzié, C.; Diao, Y.; Goto, O.; Lee, W.-Y.; Kim, Y.; Arlin, J.-B.; Karpinska, J.; Kennedy, A. R.; Parkin, S. R.; Olivier, Y.; Mannsfeld, S. C. B.; Cornil, J.; Geerts, Y. H.; Bao, Z. Adv. Mater. (Weinheim, Ger.) 2015, 27, 3066-3072. doi:10.1002/adma.201500322

51. Sugino, H.; Takimiya, K. Chem. Lett. 2017, 46, 345-347. doi:10.1246/cl.161020

52. Kohl, B.; Bohnwagner, M. V.; Rominger, F.; Wadepohl, H.; Dreuw, A.; Mastalerz, M. Chem. - Eur. J. 2016, 22, 646-655. doi:10.1002/chem.201503863

53. Wu, T.-L.; Kuo, C.-H.; Lin, B.-C.; Tao, Y.-T.; Hsu, C.-P.; Liu, R.-S. J. Mater. Chem. C 2015, 3, 7583-7588. doi:10.1039/c5tc01455g

54. Mallory, F. B.; Mallory, C. W.; Regan, C. K.; Aspden, R. J.; Ricks, A. B.; Racowski, J. M.; Nash, A. I.; Gibbons, A. V.; Carroll, P. J.; Bohen, J. M. J. Org. Chem. 2013, 78, 2040-2045. doi:10.1021/jo3020819

55. Balaraman, E.; Kumara Swamy, K. C. Tetrahedron: Asymmetry 2007, 18, 2037-2048. doi:10.1016/j.tetasy.2007.06.028 


\section{License and Terms}

This is an Open Access article under the terms of the Creative Commons Attribution License (https://creativecommons.org/licenses/by/4.0). Please note that the reuse, redistribution and reproduction in particular requires that the authors and source are credited.

The license is subject to the Beilstein Journal of Organic Chemistry terms and conditions:

(https://www.beilstein-journals.org/bjoc)

The definitive version of this article is the electronic one which can be found at:

doi:10.3762/bjoc. 16.32 